\title{
BINIVOX catalyst for hydrogen production from ethanol by low temperature steam reforming (LTSR)
}

\author{
B PATIL, S SHARMA, H K MOHANTA and B ROY* \\ Department of Chemical Engineering, Birla Institute of Technology and Science (BITS) Pilani, \\ Rajasthan 333 031, India \\ E-mail: banasri.roy@ pilani.bits-pilani.ac.in
}

MS received 17 April 2017; revised 25 July 2017; accepted 17 August 2017; published online 4 November 2017

\begin{abstract}
Nickel doped bismuth vanadate $\left[\mathrm{Bi}_{4}\left(\mathrm{~V}_{0.90} \mathrm{Ni}_{0.10}\right)_{2} \mathrm{O}_{11-\delta} ; \mathrm{BINIVOX}\right]$ calcined at $800^{\circ} \mathrm{C}$ (BINIVOX-800) catalyst is prepared by a solution combustion method. The catalytic activity study is carried in the temperature range of $250-400^{\circ} \mathrm{C}$, and with the molar feed ratios of water: ethanol at $23: 1$ and 2.5:1. The study reveals an increase in the ethanol conversion and selectivity of carbon dioxide \& hydrogen but a decrease in the selectivity of carbon monoxide and methane with an increase in temperature and water: ethanol mole ratio. Fresh and used catalysts are characterized using DTA, TGA, XRD and FTIR. XRD results reveal that the fresh catalyst is phase pure $\gamma$-BINIVOX. The phase purity and crystallinity of the catalyst is retained after $30 \mathrm{~h}$ of activity study.
\end{abstract}

Keywords. BINIVOX catalyst; catalytic activity; phase transition; crystal structure; thermal analysis.

\section{Introduction}

International Energy Outlook (IEO 2016) has predicted that the world energy demand will rise from 540.5 to 815.0 quadrillion BTU by 2014 , as the projection for world population indicates that the 8 billion marker will be reached in 2025 which is 7 billion in $2012 .{ }^{1-3}$ Conventional energy sources, in addition to their non-renewable nature, pose various problems such as environmental pollution (ozone depletion, global warming, acid rain, radioactive discharge) and health hazards (bronchial diseases, malignancy, infant mortality), effects on human health, agriculture, economy, and society are detrimental. ${ }^{4}$ Thus renewable energy sources, that are sustainable and economic at the same time, are the need of the hour. ${ }^{5}$

Out of all the renewable energy sources, hydrogen is garnering attention among environmental enthusiasts, industrial and scientific community because of its nontoxic nature, zero emission of a pollutant, high calorific value $(3100 \mathrm{kcal} / \mathrm{kg})$ and a wide range of flammability. ${ }^{6,7}$ Hydrogen is industrially manufactured by various processes like catalytic partial oxidation, steam reforming, dry reforming, decomposition of hydrocarbons,

\footnotetext{
*For correspondence
}

petroleum gasification, electrolysis, fermentation (biological ways), etc. ${ }^{7,8}$ Steam Reforming is a widely practised synthesis route owing to its high process efficiency and economic viability. Steam reforming is usually carried out at temperatures higher than $550{ }^{\circ} \mathrm{C} .{ }^{9}$ Low Temperature Steam Reforming (LTSR) is preferred due to it incurring lower operational and fixed costs, while, simultaneously offering high energy efficiency.

The renewable feedstock for hydrogen production for steam reforming is usually lighter hydrocarbons (methane, natural gas) and oxygenated hydrocarbons (alcohols, bio-oils, organic acids), out of which, we have used ethanol owing to its wide availability in India. ${ }^{10,11}$

Most common catalysts used for steam reforming are nickel(Ni), cobalt(Co), iron (Fe), copper $(\mathrm{Cu})$ (transition metals), silver( $\mathrm{Ag})$, gold $(\mathrm{Au})$, platinum $(\mathrm{Pt})$, rhodium $(\mathrm{Rh})$, ruthenium $(\mathrm{Ru})$, palladium $(\mathrm{Pd})$ (noble metals) as active phase. Alumina, ceria, zirconium oxides are used as supports usually. ${ }^{12-14}$

This work focuses on an individual group of catalysts called BIMEVOX which are complex oxides of bismuth, a metal (different transition metals such as $\mathrm{Ni}$, $\mathrm{Cu}, \mathrm{Co}, \mathrm{Mg}, \mathrm{Zn}, \mathrm{Fe}$, etc.) and vanadium. These catalysts have high oxide ion conductivity. ${ }^{15}$ These catalysts have 
been used earlier for partial oxidation of propylene in the vapour phase. ${ }^{16}$ This is the first time we are reporting the application of these catalysts for hydrogen production via steam reforming. The high oxygen conductivity can help in reduction of carbon deposition and increase water gas shift reaction and thus decrease the deactivation rate.

This work centres on preparation, characterization and activity study of BINIVOX $\left[\mathrm{Bi}_{4}\left(\mathrm{~V}_{0.90} \mathrm{Ni}_{0.10}\right)_{2} \mathrm{O}_{11-\delta \text {; }}\right.$ BINIVOX] catalyst. The catalytic activity study has been performed at different temperatures and the varied composition of feed consisting of ethanol and water. The catalytic activity study is carried out by collecting and analyzing gaseous and liquid samples with the help of GC and HS-GC, respectively. Physical and chemical properties of BINIVOX-800 catalyst (BINIVOX calcined at $800{ }^{\circ} \mathrm{C}$ ) are determined by characterizing the powders using XRD, DTA, TGA, and FTIR.

\section{Experimental}

\subsection{Catalyst Preparation}

BINIVOX-800 $\left(\mathrm{Bi}_{4}\left[\mathrm{~V}_{0.9} \mathrm{Ni}_{0.1}\right]_{2} \mathrm{O}_{11}\right)$ catalyst is synthesized by a solution combustion synthesis (SCS) method. Stoichiometric amount of bismuth nitrate $\left(\mathrm{Bi}\left(\mathrm{NO}_{3}\right)_{3} .5 \mathrm{H}_{2} \mathrm{O}\right)$ (Rankem, LR grade, purity> 99\%) (34.9 g), vanadium pentoxide $\left(\mathrm{V}_{2} \mathrm{O}_{5}\right)$ (Himedia, LR Grade, purity $>98 \%$ ) $(2.9 \mathrm{~g})$, nickel nitrate $\left(\mathrm{Ni}\left(\mathrm{NO}_{3}\right)_{2} .6 \mathrm{H}_{2} \mathrm{O}\right)$ (QLS, AR Grade, purity $>99 \%)(1.04 \mathrm{~g})$ as oxidizer and glycine $\left(\mathrm{C}_{2} \mathrm{H}_{5} \mathrm{NO}_{2}\right)$ (Rankem, LR Grade, purity > 99\%) (9.3 g) as fuel (with oxidizer to fuel ratio as 1:1) are mixed thoroughly with ethanol in a $500 \mathrm{cc}$ beaker. The mixture is left overnight for drying at room temperature. The homogenous paste is heated to $300^{\circ} \mathrm{C}$ over a heating plate inside the fume hood to ensure security. The mixture is self-ignited in one place and spread throughout the beaker eventually, turning it into a black fluffy mass. The obtained mass is washed three to four times with DI water to remove the un-reacted salts and fuel and dried at $60^{\circ} \mathrm{C}$ for 12 h. Finally, it is calcined at $800^{\circ} \mathrm{C}$ for $2 \mathrm{~h}$. This catalyst from now on is called as BINIVOX-800. The SCS method has been explained as a flowchart in Figure 1.

\subsection{Catalyst Characterization}

Simultaneous thermogravimetric and differential thermal analysis (S- DTG; Shimadzu, DTG-60H) of the dried powder is carried out in the presence of air from 30 to $800^{\circ} \mathrm{C}$ at a rate of $5^{\circ} \mathrm{C}$ per min rise in temperature. DTA data of the catalyst is also collected during the cooling cycle from 800 to $200^{\circ} \mathrm{C}$.

The X-ray diffraction data of the fresh and used BINIVOX800 is acquired by Rigaku Miniflex II with the help of $\mathrm{CuK} \alpha$ radiation $(1.5 \AA, 15 \mathrm{~mA}, 30 \mathrm{kV})$. The sample is scanned at $2^{\circ} / \min$ from 20 to $60^{\circ}$.

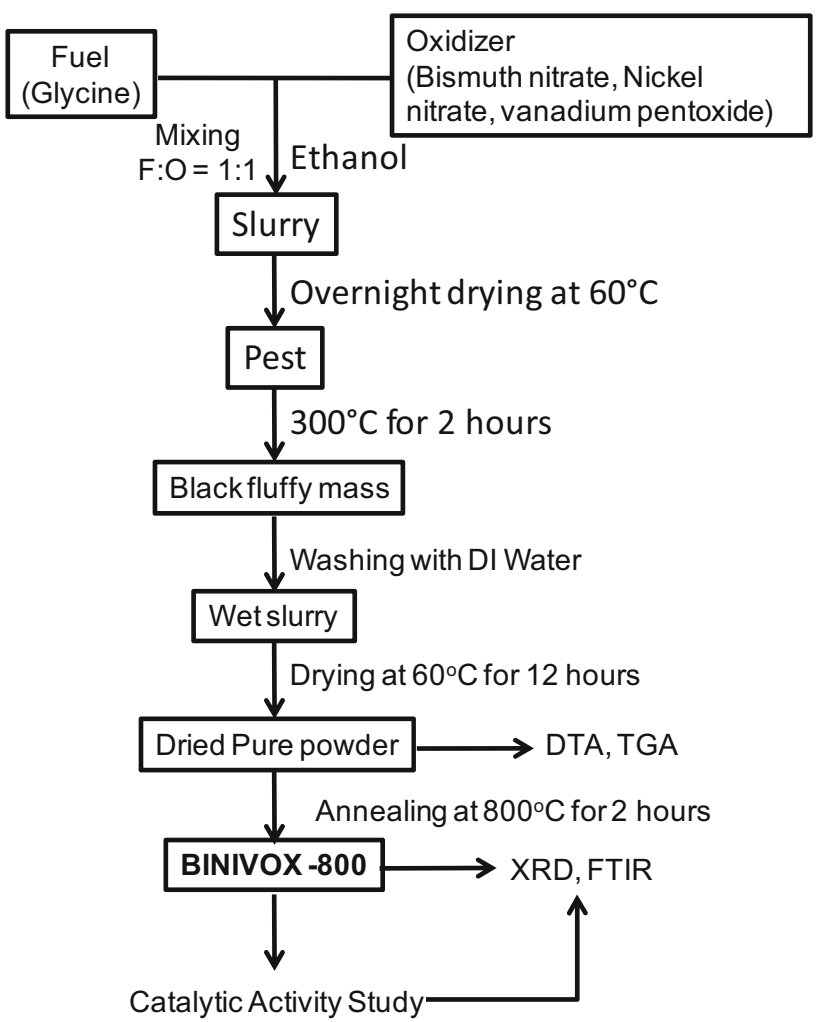

Figure 1. Flowchart for the solution combustion synthesis method used for the preparation of BINIVOX catalyst and the corresponding characterizations.

Fourier Transform Infrared (FTIR) spectroscopy analysis of the catalyst is performed by a Perkin Elmer Frontier ${ }^{\mathrm{TM}}$ within the wavenumber range of 400 to $4000 \mathrm{~cm}^{-1}$. The data is averaged over 20 scans.

\subsection{Catalyst Activity Study}

Catalytic activity studies are conducted in a custom-made Utube packed bed reactor (inner diameter of 3/8 inch) sited inside a muffle furnace. $2 \mathrm{~g}$ of the catalyst powder is loaded into the reactor. Water: ethanol mixture of $2.5: 1$ and 23:1 mole ratio is preheated to $110^{\circ} \mathrm{C}$. Pure nitrogen gas $(99.99$ $\%)$ swept through the preheater and carries vapour to the reactor. The vapour conducting ducts are maintained at $110^{\circ} \mathrm{C}$ by wrapping heating tape around them in order to avoid the condensation of the feed vapour. An ice cooled phase separator is used to separate liquid and gaseous parts of the product coming out of the reactor. The gaseous products are analyzed at an interval of each hour for $6 \mathrm{~h}$. A gas chromatograph instrument (Shimadzu gas chromatograph (GC - 2014)) with porapak as reference column and carbosphere as sample column with thermal conductivity detector (TCD) is used for the purpose. The liquid products are collected at the end of $6 \mathrm{~h}$ and are analyzed by a GC- HS (Shimadzu model no.10) equipped with Flow Ionization Detector (FID). The schematic of the experimental setup is shown in Figure 2. 


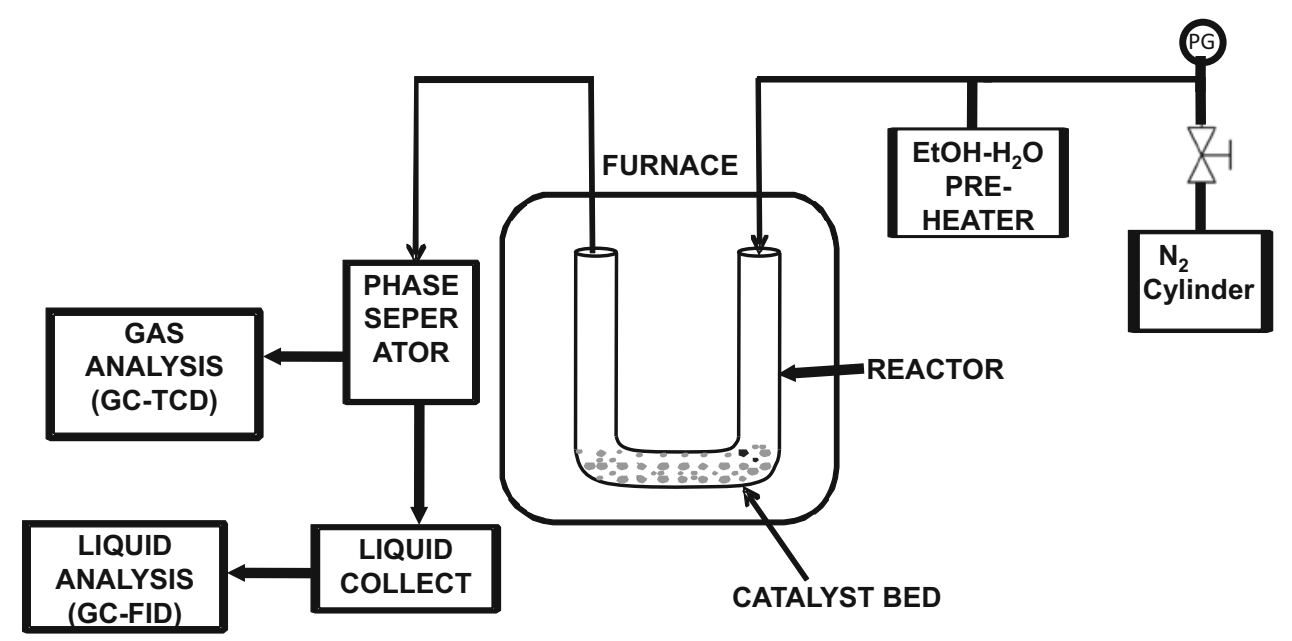

Figure 2. Schematic of low temperature steam reforming experimental set up.

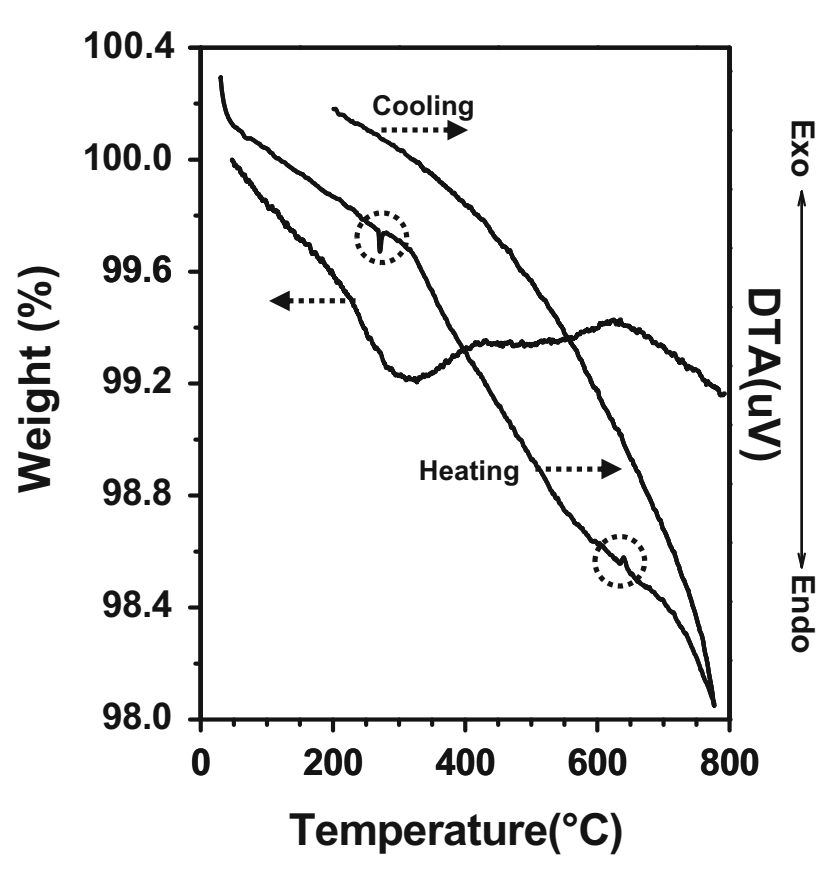

Figure 3. DTA/TGA spectra for BINIVOX powder.

\section{Results and Discussion}

\subsection{Characterization Results}

3.1a S-DTG Analysis: Figure 3 show the DTA and TGA profiles of the dried powder. Thermogravimetric analysis shows that there is a $\sim 0.8 \%$ decrease in weight at $\sim 305^{\circ} \mathrm{C}$ accompanied by an endothermic DTA peak. This could be attributed to the loss of surface moisture, volatile organic materials and/or some $\mathrm{Bi}-\mathrm{V}-\mathrm{O}$ related phase change. ${ }^{17}$ The exothermic DTA peak at $\sim 640{ }^{\circ} \mathrm{C}$ may correspond to some phase change in the sample. The DTA cooling spectrum devoid of any phase reversal peak indicates the stability of the catalyst. Figure 4

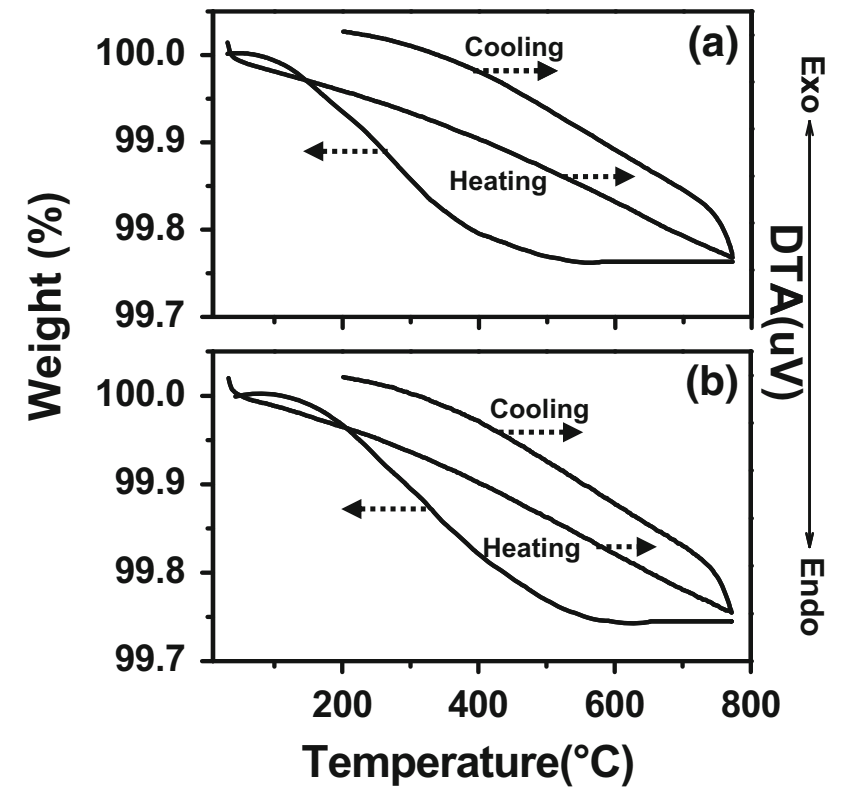

Figure 4. DTA/TGA spectra for BINIVOX -800 (a) fresh and (b) used catalyst.

shows the DTA and TGA spectra for BINIVOX-800 (a) fresh and (b) used catalyst. DTA spectra show that there is no change in phase during heating and cooling both, after $30 \mathrm{~h}$ of the experiment. TGA analysis shows that there is $\mathrm{a} \sim 0.24 \%$ and $\sim 0.26 \%$ decrease in weight for the fresh and used catalyst, respectively. The change in weight is observed only minimal $(\sim 0.02 \%)$, which could be attributed to $\mathrm{C}$ deposition (DTA has no peak) on the catalyst. This indicates the stability (in terms of phase content and activation) of the catalyst.

3.1b XRD Analysis: From the X-Ray diffraction spectra of the fresh and used samples (Figure 5), it could be inferred that the heat treated $\left(800^{\circ} \mathrm{C}\right.$ for $\left.2 \mathrm{~h}\right)$ catalyst 


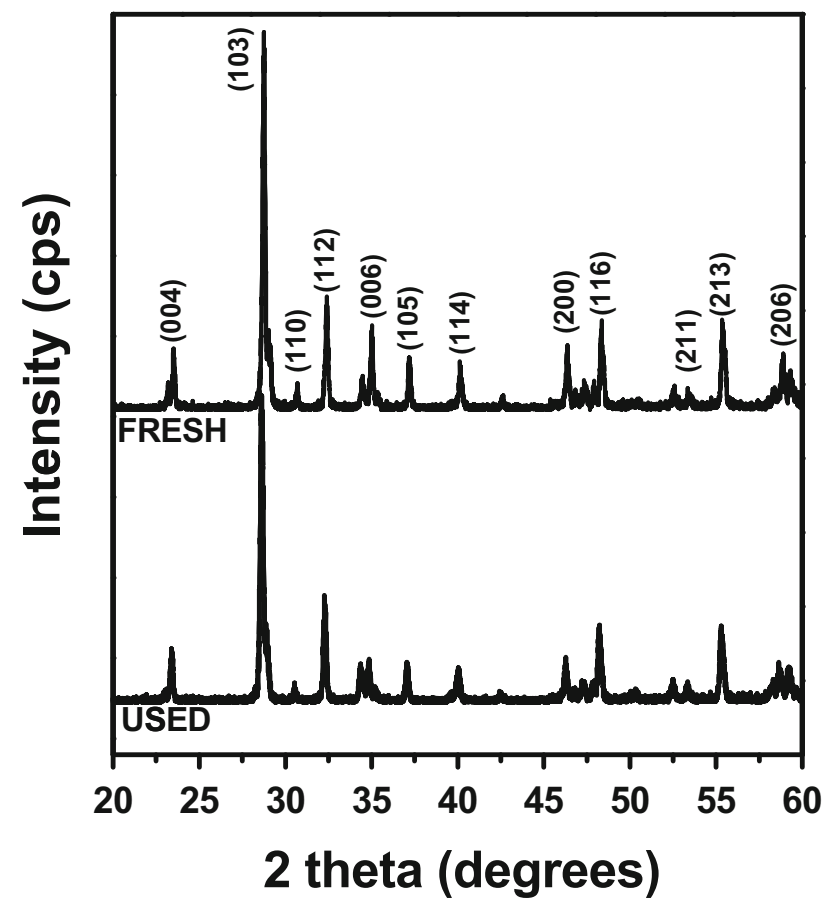

Figure 5. XRD spectra of the BINIVOX-800 catalysts, fresh and used.



Figure 6. FTIR images of the BINIVOX-800 fresh and used catalysts.

is essentially single-phase $\gamma$-BINIVOX. ${ }^{18,19}$ The used catalyst (after $30 \mathrm{~h}$ of the experiment) shows almost no sign of degradation in terms of phase composition and retains good crystallinity (within $10 \%$ of the fresh one; Table S1) almost similar to the fresh one. These results are in accordance with the DTA analysis.

3.1c FTIR Analysis: The FTIR spectra of BINIVOX800 , before and after use are depicted in Figure 6. The peak at $2770 \mathrm{~cm}^{-1}$ exhibits the presence of O-H stretch. This corresponds to the moisture adsorbed by the catalyst. Apart from these, the FTIR also shows peaks in-between $995-1203 \mathrm{~cm}^{-1}$ set for the asymmetric V-O stretching $\left(\mathrm{V}_{A S}\right)$ of vanadate ions. The peak at $709 \mathrm{~cm}^{-1}$ corresponds to a symmetric $\mathrm{V}-\mathrm{O}$ stretching $\left(\mathrm{V}_{S}\right)$ of vanadate ions. The peak at $478 \mathrm{~cm}^{-1}$ could be attributed to the vibration of the $\mathrm{Bi}-\mathrm{O}$ band of bismuth oxide. ${ }^{18,20}$

\subsection{Catalytic Activity Study}

Gaseous products obtained by steam reforming of ethanol consist of hydrogen, carbon monoxide, carbon dioxide and methane. The percentage (\%) selectivity of the individual products is calculated using the following equations. ${ }^{21,22}$

$$
\begin{aligned}
\mathrm{H}_{2} \text { selectivity }(\%) & =\frac{x_{\mathrm{H}_{2}}}{3 x_{\mathrm{CO}_{2}}} \times 100 \\
\mathrm{CO}_{2} \text { selectivity }(\%) & =\frac{x_{\mathrm{CO}_{2}}}{x_{\mathrm{CO}_{2}}+x_{\mathrm{CH}_{4}}+x_{\mathrm{CO}}} \times 100 \\
\mathrm{CO} \text { selectivity }(\%)= & \frac{x_{\mathrm{CO}}}{x_{\mathrm{CO}_{2}}+x_{\mathrm{CH}_{4}}+x_{\mathrm{CO}}} \times 100 \\
\mathrm{CH}_{4} \text { selectivity }(\%)= & \frac{x_{\mathrm{CH}_{4}}}{x_{\mathrm{CO}_{2}}+x_{\mathrm{CH}_{4}}+x_{\mathrm{CO}}} \times 100 \\
\text { Ethanol conversion }= & \left(\left(\mathrm{mol} \mathrm{EtOH}_{\mathrm{in}}-\mathrm{mol} \mathrm{EtOH}_{\mathrm{out}}\right) /\right. \\
& \left.\mathrm{mol} \mathrm{EtOH}_{\mathrm{in}}\right) \times 100
\end{aligned}
$$

Experimental results indicate that the selectivity of the products attains steady state after five hours and almost remains constant for next $20 \mathrm{~h}$ indicating that the catalyst is stable over $25 \mathrm{~h}$ which is in accordance with the X-ray Diffraction and DTA/TGA results.

Figure 7 shows the changes in ethanol conversion (\%), product selectivity (\%) in the gaseous phase and carbon $(\%)$ in the gas phase with temperature. As temperature and the feed composition of water: ethanol (2.5:1 and 23:1 mole ratio) increase ethanol conversion increases. The similar results have been established by RomeroSarria $\mathrm{F}$ et $a l .{ }^{23}$ With the increase in steam content in the feed to the reactor, there is enhanced $\mathrm{C}-\mathrm{C}$ and $\mathrm{C}$ $\mathrm{O}$ bond cleavage. The lowest and the highest ethanol conversion $(42 \%$ and $75 \%)$ is observed at $250{ }^{\circ} \mathrm{C}, \mathrm{H}_{2} \mathrm{O}$ : $\mathrm{EtOH}=2.5: 1$ mole ratio and $400{ }^{\circ} \mathrm{C}, \mathrm{H}_{2} \mathrm{O}: \mathrm{EtOH}=23: 1$ mole ratio, respectively.

Figures 7(b), 7(c), 7(d) and 7(e) reveal the rise of the hydrogen and carbon dioxide selectivity and drop in carbon monoxide and methane selectivity with respect to the temperature for both feed concentration. At the feed composition of $\mathrm{H}_{2} \mathrm{O}: \mathrm{EtOH}=23: 1$, the highest hydrogen and carbon dioxide selectivity are recorded 

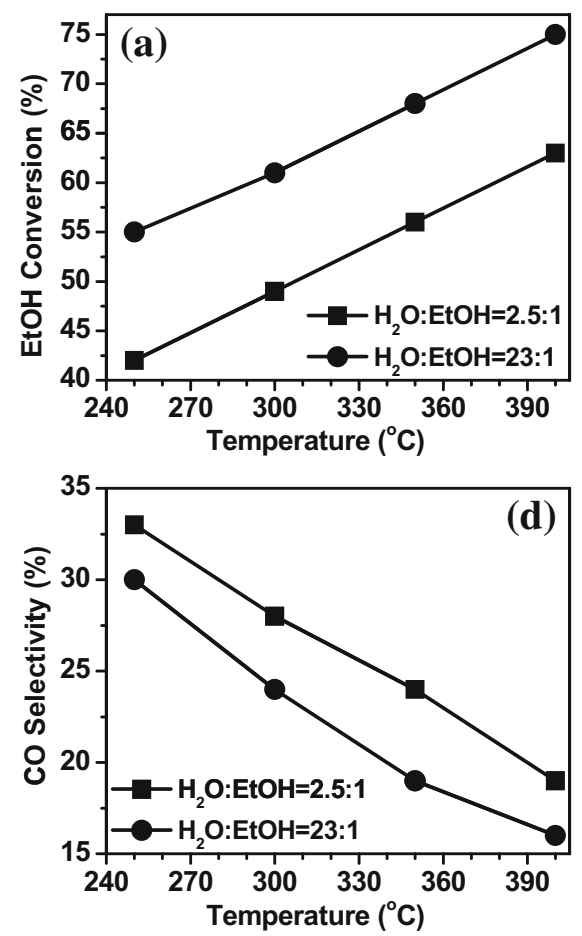
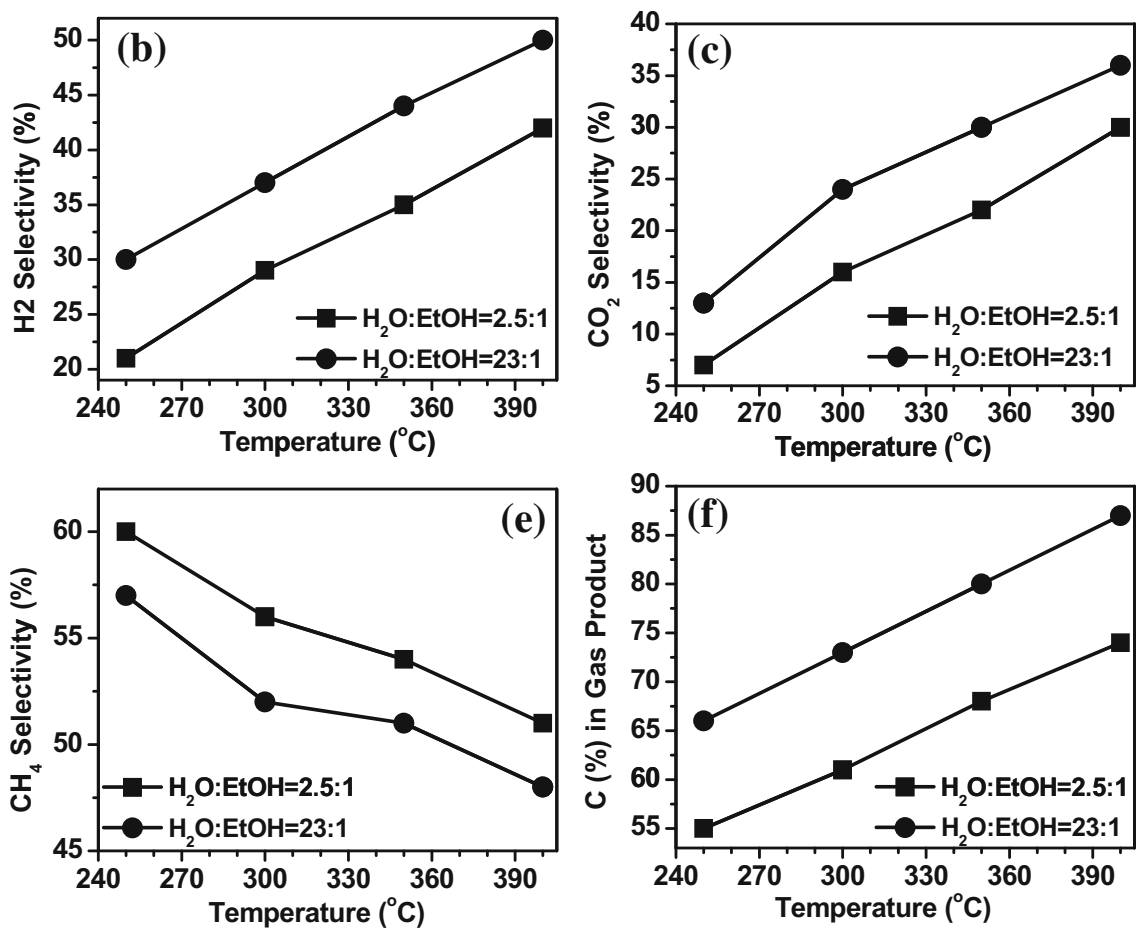

Figure 7. Catalytic activity as a function of temperature for the BINIVOX-800 powder for low temperature steam reforming of ethanol- $\mathrm{H}_{2} \mathrm{O}$ mixture at two different mol ratio; (a) ethanol conversion (\%) (b) $\mathrm{H}_{2}$ selectivity (\%), (c) $\mathrm{CO}_{2}$ selectivity (\%), (d) $\mathrm{CO}$ selectivity (\%), (e) $\mathrm{CH}_{4}$ selectivity (\%), and (f) $\mathrm{C}$ in gas product (\%).

to be 50 and $35 \%$, respectively at $400{ }^{\circ} \mathrm{C}$, which are, 140 and $600 \%$, respectively, larger than the selectivity observed at the lowest reaction temperature $\left(250^{\circ} \mathrm{C}\right)$. The lowest selectivity values of carbon monoxide and methane are noticed to be 16 and $48 \%$, respectively, at $400{ }^{\circ} \mathrm{C}$ and water: $\mathrm{EtOH}=23: 1$ mole ratio. Supplementary word file is provided to show the carbon balance.

Reportedly, at lower steam reforming temperature (200 to $500^{\circ} \mathrm{C}$ ), ethanol undergoes the direct decomposition yielding carbon monoxide, methane and hydrogen (eq. 6). ${ }^{21,23,24}$

$\mathrm{C}_{2} \mathrm{H}_{5} \mathrm{OH} \rightarrow \mathrm{CH}_{4}+\mathrm{CO}+\mathrm{H}_{2} ; \quad \Delta \mathrm{H}^{\circ}=49 \mathrm{~kJ} / \mathrm{mol}$

That can be followed by methane steam reforming reaction to produce carbon dioxide and hydrogen (eq. 7).

$\mathrm{CH}_{4}+2 \mathrm{H}_{2} \mathrm{O} \leftrightarrow 4 \mathrm{H}_{2}+\mathrm{CO}_{2} ; \quad \Delta \mathrm{H}^{\circ}=164.5 \mathrm{~kJ} / \mathrm{mol}$

At the similar low temperature, water gas shift reaction can also take place (eq. 8).

$\mathrm{CO}+\mathrm{H}_{2} \mathrm{O} \rightarrow \mathrm{CO}_{2}+\mathrm{H}_{2} ; \quad \Delta \mathrm{H}^{\circ}=-40 \mathrm{~kJ} / \mathrm{mol}$

Higher reaction temperature $\left(550^{\circ} \mathrm{C}\right)$ favours direct ethanol steam reforming to produce carbon dioxide (and/or CO) and hydrogen (eqs. 9 and 10).

$$
\begin{array}{ll}
\mathrm{C}_{2} \mathrm{H}_{5} \mathrm{OH}+3 \mathrm{H}_{2} \mathrm{O} \leftrightarrow 6 \mathrm{H}_{2}+2 \mathrm{CO}_{2} ; & \Delta \mathrm{H}^{\circ}=173.3 \mathrm{~kJ} / \mathrm{mol} \\
\mathrm{C}_{2} \mathrm{H}_{5} \mathrm{OH}+\mathrm{H}_{2} \mathrm{O} \leftrightarrow 4 \mathrm{H}_{2}+2 \mathrm{CO}_{2} ; & \Delta \mathrm{H}^{\circ}=260 \mathrm{~kJ} / \mathrm{mol}
\end{array}
$$

Here, our results show that higher water: ethanol ratio favours methane reforming and water gas shift reaction, as expected. ${ }^{24-27}$

\section{Conclusion}

BINIVOX catalyst annealed at $800{ }^{\circ} \mathrm{C}$ can be used for the production of hydrogen by low temperature steam reforming of ethanol. The preliminary catalytic activity study shows the significant formation of hydrogen and carbon dioxide in the product gas. Carbon dioxide is observed to be produced at temperatures as low as $250{ }^{\circ} \mathrm{C}$. There is an increase in the selectivity of hydrogen, carbon dioxide and a decrease in the selectivity of methane and carbon monoxide with the increase in reaction temperature and water: ethanol mole ratio. This probably indicates methane steam reforming and water gas shift reaction capacity of the catalyst at low temperature. According to XRD and S-DTG analysis, the fresh catalyst is a phase pure $\gamma$ - BINIVOX and retains its crystallinity and phase purity till after 30 hours of activity study. 


\section{Supplementary Information (SI)}

The comparative peak width data of the fresh and used catalysts are demonstrated in Table S1. The detailed carbon balance related calculation procedure (flow rate, Ethanol conversion and Carbon in gas and liquid phases, etc.,) is provided in SI available at www.ias.ac.in/ chemsci.

\section{Acknowledgements}

The authors would like to thank the Department of Chemical Engineering, Birla Institute of Technology (BITS), Pilani, Pilani Campus for providing the utilities to conduct the experiments. Authors also would like to gratefully acknowledge the department of physics BITS Pilani for conducting the XRD.

\section{References}

1. Demirbas A 2001 Biomass resource facilities and biomass conversion processing for fuels and chemicals Energy Convers. Manage. 421357

2. EIA projects $48 \%$ increase in world energy consumption by 2040 http://www.eia.gov/todayinenergy/detail.php? $\mathrm{id}=26212$ (accessed on 15 January 2017)

3. U.S. and World Population Clock, Source: U.S. Census Bureau, International Data Base (demographic data) and USA Trade Online (trade data)

4. https://www.census.gov/popclock/world (accessed on 15 July 2017)

5. McMichael A J 2000 The urban environment and health in a world of increasing globalization: Issues for developing countries. Bulletin of the World Health Organization 781117

6. Hua T, Ahluwalia R, Eudy L, Singer G, Jermer B, Asselin-Miller N, Wessel S, Patterson T and Marcinkoski J 2014 Status of hydrogen fuel cell electric buses worldwide J. Power Sources 269975

7. Rostrup-Nielsen J R 1975 Steam Reforming Catalysts Danish Technical Press Copenhagen 1975

8. Dal Santo V, Gallo A, Naldoni A, Guidotti M and Psaro M 2012 Bimetallic heterogeneous catalysts for hydrogen production Catal. Today 197190

9. Jalowiecki-Duhamel, Pirez C, Capron M, Dumeignil F and Payen E 2010 Hydrogen production from ethanol steam reforming over cerium and nickel based oxyhydrides Int. J. Hydrogen Energ. 3512741

10. Kumar A, Prasad R and Sharma Y C 2014 Steam reforming of ethanol: production of renewable hydrogen Int. J. Environ. Res. Dev. 4203

11. Kalamaras C M and Efstathiou A M 2013 Hydrogen production technologies: current state and future developments Energy 2013

12. https://policyblog.oxfordindiasociety.org.uk/2013/04/02 /the-curious-case-of-indias-bioethanol-biofuel-policydoomed-for-failure/ (accessed on 16 January 2017)

13. Doukkali M E, Iriondo A, Arias P L, Requies J, Gandarías I, Jalowiecki-Duhamel and Dumeignil F 2012 A comparison of sol-gel and impregnated $\mathrm{Pt}$ or/and $\mathrm{Ni}$ based $\gamma$-alumina catalysts for bioglycerol aqueous phase reforming Appl. Catal. B-Environ. 125516

14. Doukkali M E, Iriondo A, Cambra J F, Gandarías I, Jalowiecki-Duhamel, Dumeignil F and Arias P L 2014 Deactivation study of the Pt and/or Ni-based $\gamma-\mathrm{Al}_{2} \mathrm{O}_{3}$ catalysts used in the aqueous phase reforming of glycerol for $\mathrm{H}_{2}$ production Appl. Catal. A-Gen. 47280

15. Ni M, Leung D Y C and Leung M K H 2007 A review on reforming bio-ethanol for hydrogen production Int. J. Hydrogen Energ. 323238

16. Boivin, J C, Pirovano C, Nowogrocki G, Mairesse G, Labrune Ph and Lagrange G 1998 Electrode-electrolyte BIMEVOX system for moderate temperature Solid State Ionics 113-115 639

17. Qiying J, Faraji S, Slade D A and Stagg-Williams S M 2011 In Inorganic, Polymeric and Composite Membranes: Structure-Function and Other Correlations Membrane Science and Technology $14^{\text {th }}$ edn. (Amsterdam: Elsevier) p. 235

18. Danley R L and Schaefer J W 2008 System and method for a Thermogravimetric Analyzer having improved dynamic weight baseline U.S. Patent 7,416,328

19. Beg S, Al-Areqi N A, Hafeez S and Al-Alas A 2015 Improved structural and electrical properties of nickel and aluminum co-doped $\mathrm{Bi}_{4} \mathrm{~V}_{2} \mathrm{O}_{11}$ solid electrolyte Ionics 21421

20. Roy B and Fuierer P A 2009 Synthesis of cobalt-doped bismuth vanadate by combustion-synthesis: Influence of fuel on phase content and morphology J. Mater. Res. 24 3078

21. Tolstoy V P and Tolstobrov E V 2002 The synthesis of $\mathrm{Bi}-\mathrm{V}-\mathrm{O}$-containing nanolayers on silica surfaces by the successive ionic layer deposition technique Solid State Ionics $\mathbf{1 5 1} 165$

22. Roy B, Sullivan $\mathrm{H}$ and Leclerc C A 2011 Aqueous-phase reforming of $\mathrm{n}-\mathrm{BuOH}$ over $\mathrm{Ni} / \mathrm{Al}_{2} \mathrm{O}_{3}$ and $\mathrm{Ni} / \mathrm{CeO}_{2}$ catalysts J. Power Sources 19610652

23. Akande A, Aboudheir A, Idem R and Dalai A 2006 Kinetic modeling of hydrogen production by the catalytic reforming of crude ethanol over a co-precipitated $\mathrm{Ni}-\mathrm{Al}_{2} \mathrm{O}_{3}$ catalyst in a packed bed tubular reactor Int. J. Hydrogen Energ. 311707

24. Romero-Sarria F, Varga J C, Roger A C and Kiennemann A 2008 Hydrogen production by steam reforming of ethanol: Study of mixed oxide catalysts $\mathrm{Ce}_{2} \mathrm{Zr}_{1.5} \mathrm{Me}_{0.5} \mathrm{O}_{8}$ : Comparison of $\mathrm{Ni} / \mathrm{Co}$ and effect of Rh Catal. Today 133149

25. Deluga G A, Salge J R, Schmidt L D and Verykios X E 2004 Renewable hydrogen from ethanol by autothermal reforming Science $\mathbf{3 0 3} 993$

26. Bineli A R and Tasić M B 2016 Catalytic steam reforming of ethanol for hydrogen production: Brief status Chem. Ind. Chem. Eng. Q 22327

27. Memon M Z, Zhao X, Sikarwar V S, Vuppaladadiyam A K, Milne S J, Brown A P and Zhao M 2016 Alkali metal $\mathrm{CO}_{2}$ sorbents and the resulting metal carbonates: Potential for process intensification of Sorption-Enhanced Steam Reforming Environ. Sci. Technol. 5112

28. Bej B, Pradhan N C and Neogi S 2014 Production of hydrogen by steam reforming of ethanol over alumina supported nano-NiO/ $\mathrm{SiO}_{2}$ catalyst Catal. Today 23780 